\title{
Guest Editorial: Sustainability and the BP oil spill
}

\author{
Stuart Kirsch
}

Published online: 17 August 2010

(C) Springer Science+Business Media B.V. 2010

I recently attended a symposium at my university on how to integrate sustainability into the curriculum, a topic of interest to me as an anthropologist who works with indigenous peoples affected by mining (Kirsch 2006). ${ }^{1}$ We were told that the university and the corporate world were now aligned in their shared commitment to sustainability. But I wondered why no one mentioned the BP oil spill in the Gulf of Mexico, which was making headlines. I wanted to know what it meant that business and the academy suddenly seemed to be speaking a common language. Surely I was not the only one in the audience with these concerns, but the question left us tonguetied. It is almost impossible to criticize sustainability in principle, as the environmental values it promotes are widely shared. ${ }^{2}$ Yet, it is possible to acknowledge the need for sustainability while contesting some of the claims made in its name. Consequently, this editorial addresses the questions I wish we had discussed at the symposium.

The BP oil spill highlights the stakes involved in corporate claims about sustainability. These events have become intimately familiar to us through images of underwater oil plumes, polluted wetlands, and brown pelicans coated in oil. We hear the stories of out-of-work fishermen and others who have lost their livelihoods to the disaster. These events beg the question whether corporate discourse on sustainability represents a market shift in how business operates or just a shift in how corporations market themselves. Not everyone remembers that BP was one of the first major transnational corporations to rebrand itself as green by invoking the language of sustainability. Stung by public criticism of its operations, British

\footnotetext{
1 The conference organizers invoked the definition of the Brundtland Commission (1987): "Sustainable development meets the needs of the present without compromising the ability of future generations to meet their own needs.".

2 See Marilyn Strathern's (2000:3, 14) comments on audit culture.
}

S. Kirsch (ه)

University of Michigan, Ann Arbor, MI, USA

e-mail: skirsch@umich.edu 
Petroleum broke ranks with the other major oil producers in 1997 by leaving the Global Climate Coalition, a group of 50 corporations and trade associations, which argued that there was insufficient scientific information to confirm the threat of global warming, and therefore actions undertaken to limit the accumulation of greenhouse gases were unwarranted (Beder 2002). BP's new green and yellow logo was intended to symbolize its shift toward cleaner energy sources. The company even adopted a corporate oxymoron, Beyond Petroleum, as its new name. The pairing of a harmful product with a desirable cover term is "intended to ease the mind of an otherwise critical consumer" (Benson and Kirsch 2010:47). However, BP spent far more on its rebranding exercise than it did on solar power (Bruno 2000).

The scale of the BP oil spill in the Gulf of Mexico, equivalent to more than one Exxon Valdez disaster per week, and its constant exposure through the media may make this particular event seem exceptional. In fact, BP has a poor environmental track record. There is a telling story about the BP oil pipeline in Prudhoe Bay, Alaska, which began to leak in 2006 (Uhlmann 2010). The company had known that the pipeline had problems for a number of years. At first, BP was reluctant to invest the financial resources to make the necessary repairs because oil prices were relatively low. When the market picked up again, however, the company did not want to shut down the pipeline long enough to make the repairs while oil prices were so high. Their short-sighted economic calculus resulted in oil spills along the pipeline. BP clearly preferred the old green (money, profit) to the new green (sustainability, environmental responsibility). ${ }^{3}$

Given BP's questionable commitment to sustainability, one must look for other explanations for its claim to virtue. Perhaps, like St. Augustine, the company has been praying for help in giving up sin, although not just yet-not while it is still earning so much money. ${ }^{4}$ An alternative motivation for promoting itself as sustainable might be the desire to reduce the costly friction of regulation and critique. Contemporary corporations also seek to render environmental activism obsolete by redefining environmentalism as a responsibility they have already internalized (Hoffman 1997). The business community divides environmentalists into two groups: the light greens who view the market as the solution to environmental problems and are willing to collaborate with corporations, and the dark greens who view the market as part of the problem and remain critical of corporate claims to virtuous self-improvement. The corporate version of divide and conquer identifies some NGOs as realist and productive, while dismissing the remainder as radical and counterproductive. Perhaps deployment of the virtuous discourse of sustainability helps keep critics at bay for all but the worst case scenarios, such as the Deepwater Horizon oil spill in the Gulf of Mexico.

What are the consequences of importing the corporate discourse of sustainability into the academy? Consider the corporations invited to serve as members of the

\footnotetext{
${ }^{3}$ BP subsequently pled guilty to violations of the Clean Water Act in relation to the Prudhoe Bay pipeline leak (Uhlmann 2010).

${ }^{4}$ Not even Credit Suisse's estimate (from 2 June, 2010) that the clean-up for the Gulf oil spill will cost BP $\$ 40$ billion is likely to bankrupt a company that earned $\$ 17$ billion profit in 2009 , as the clean-up costs will be spread out over a number of years.
} 
external advisory board at the new institute on sustainability at my university. ${ }^{5}$ BHP Billiton is one of the world's largest resource companies. It is also responsible for the Ok Tedi copper and gold mine in Papua New Guinea, which has caused extensive environmental damage downstream (Kirsch 2006). After studies revealed that damage from the project would eventually affect more than two thousand square kilometers of rain forest and last for several centuries, BHP Billiton transferred its 52 percent share of the project to an offshore development trust in exchange for a waiver of environmental liability (Economist 1999). At no point did the mining company consider investing the financial resources to clean up the disaster downstream from the mine, as BP is being forced to do for its oil spill in the Gulf of Mexico. When the Chronicle of Higher Education reported on the irony of appointing BHP Billiton an external advisor on sustainability, the interim director of the institute, a professor of business administration, defended his selection of the company in the following terms: "I have no reason to doubt that this company has really screwed a lot of people', just as nearly every other company is 'unjust to people' at one point or another.... 'These organizations are part of the problem, and they're also part of the solution"” (Blumenstyk 2007). A funding request to bring a speaker from Papua New Guinea to campus to discuss the environmental impacts of the Ok Tedi mine was turned down by the university's center for ethics in public life, because it was deemed to be too controversial and too critical of the institute on sustainability. Plans to debate the role of corporations on campus also failed to materialize. Several colleagues discouraged me from speaking up or writing about these interactions, although my department chair demonstrated his support by reprinting the Chronicle essay in his anthropology textbook (Kottak 2009:542-543).

Similar questions can also be raised about the other corporate advisors to the university's institute on sustainability. Shell Oil has been widely criticized for its disastrous oil spills in the Niger Delta and alleged collusion with the repressive Nigerian government (Watts and Kashi 2008). The CEO of Duke Energy has been a tireless promoter of a cap-and-trade carbon management system that would net his company tens of billions in carbon credits for having kept its coal-burning power plants on-line (Thompson 2008). ${ }^{6}$ How can companies with environmental track records like those of BHP Billiton, Shell Oil, and Duke Energy provide the university with credible advice on issues of sustainability?

All three of these companies have multiple affiliations and relationships on campus. BHP Billiton funds faculty and graduate student research, offers internships, has given presentations on the engineering challenges posed by its mining projects, and is a sponsor of the university's solar car (see Fig. 1). Shell Oil is a significant corporate donor to the engineering school and the center for the education of women. Duke Energy offers student internships, and several of its executives have been invited speakers on campus. For faculty to criticize these companies on their environmental records now requires taking on colleagues from

\footnotetext{
5 The full list of external advisory board members of the Graham Environmental Sustainability Institute is available online: http://www.graham.umich.edu/about/eab.php.

6 Duke Energy is the third-largest corporate producer of carbon dioxide emissions in the United States (Thompson 2008).
} 


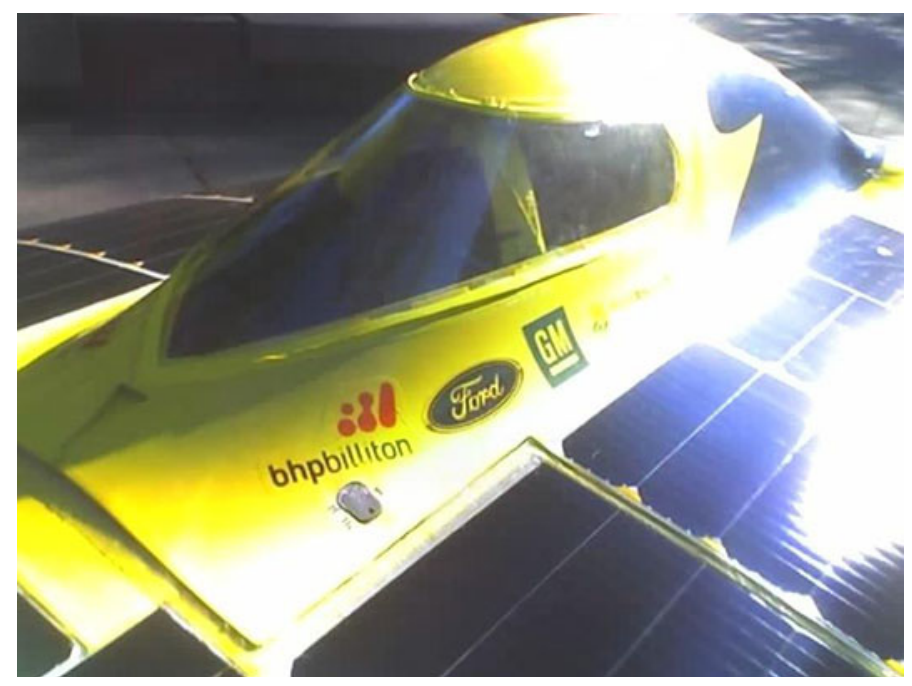

Fig. 1 The logo of the company responsible for the Ok Tedi mining disaster is prominently displayed on the University of Michigan's solar car. Photo credit: Stuart Kirsch

across the university who have vested interests in supporting these companies rather than carefully evaluating their performance. As the interim director of the institute on sustainability suggested in his comments to the Chronicle of Higher Education, many of my colleagues are either unaware or unconcerned about the environmental problems caused by the companies with which they collaborate or from which they receive funding.

Several of the largest conservation organizations have also come under scrutiny for their ties to the corporate world. The World Wildlife Fund, Conservation International, and the Nature Conservancy have been criticized for "allying themselves with the forces that are destroying the world's remaining ecosystems" (Chapin 2004:26), including the petroleum and mining industries. Since the Deepwater Horizon oil spill, the Nature Conservancy has been criticized for collaborating with BP, including its acceptance of nearly $\$ 10$ million in cash and land, its seat on the company's International Leadership Council, and its enhancement of the company's environmental image (Stephens 2010). The Nature Conservancy has vigorously defended its relationship with BP, including an attempt to shift responsibility for the oil spill from the company (and its reckless disregard for the risks it was taking) to consumer demand for oil, by suggesting that we should drive less rather than blame BP for supplying the oil we asked for (Finch 2010).

As this example suggests, the neoliberal response to environmental disaster is to transfer responsibility from corporations to consumers. The philosophy of green consumerism asserts that consumer preference will be more effective in changing corporate behavior than government regulation (Speth 2008). In this formulation, political agency is equated with purchasing power; one must literally buy into the system to express one's point of view. Green consumerism also offers a striking example of how political sentiments are converted into non-political modes of 
action; the transformation of the environmental movement into green consumerism makes the world safe for shopping as usual.

One of the primary limitations of green consumerism is that it does nothing to reduce the overall rate of consumption and may in fact legitimate continued overconsumption. An example of this phenomenon is the emergence of the green McMansion, which uses recycled or green building materials but is still oversized. Another shortcoming of green consumerism is the lack of environmentally friendly alternatives for many of our regular purchases. Consider my dilemma in filling up my car. Since I purchase gasoline directly from the producer, in theory I should be able to exercise my consumer preferences at the pump. I won't choose BP given its responsibility for the nation's largest oil spill. ${ }^{7}$ Do I really want to give Exxon Mobil my business given the way the company fought to reduce punitive damages awarded after the Exxon Valdez spill? What about the Shell station on the corner? Not after reading about the harm Shell Oil has caused the Ogoni people living in the Niger Delta. What about Chevron Texaco? They are being sued for billions of dollars after allegedly failing to clean up their oil spills in the Ecuadorian Amazon. For Americans who drive, there are no green choices apart from taking the bus, riding a bike, or walking, which are impractical for many people. There are significant limits on our ability to shop our way to a greener planet.

Many desirable changes have been encouraged by the discourse of sustainability. Corporations have become serious about adopting greener forms of energy and construction, especially in showcase venues like the green roof on Ford's new truck plant in their historic Rouge complex outside Detroit. Many manufacturers are committed to reducing their contribution to the waste stream and developing product designs that facilitate eventual recycling, even as many industries remain based on financial models that require ever-diminishing cycles of replacement. ${ }^{8}$

However, the discourse of sustainability can also help protect corporations from critique. Corporate deployment of the language of virtue makes criticism awkward. Yet, the role played by corporate critics may never have been as important as today given the current era of neoliberalism and deregulation, in which the state has largely abandoned its historical responsibility for protecting its citizens. In many cases, only the critic is left to monitor the environmental impact of corporations, to bring these problems to the attention of the public, and to demand expenditure of sufficient political capital to impose a solution. The steady infiltration of corporate capital into universities has made this role increasingly difficult for academics to play.

In the wake of the oil spill in the Gulf of Mexico, BP has been publishing full page newspaper ads in which it asserts: "We will make this right." Leaving aside the question whether an oil spill of this magnitude can ever be adequately cleaned up, it is clear that only extraordinary pressure from BP's critics has forced the company to take responsibility for the clean-up, not its voluntary commitment to the discourse of sustainability.

\footnotetext{
${ }^{7}$ Although BP sells gas to numerous distributors and the gasoline sold at BP stations may come from other oil companies.

${ }^{8}$ For example, the number of discarded cell-phones, a relatively new mass consumer product, must already be in the billions.
} 
Acknowledgments I am grateful to Kirk Dombrowski and the editorial board of Dialectical Anthropology for the opportunity to express my views; I also thank Jessica Smith Rolston for her helpful comments.

\section{References}

Beder, Sharon. 2002. BP: beyond petroleum? In Battling big business: countering greenwash, infiltration, other forms of corporate bullying, ed. Eveline Lubbers, 26-32. Devon: Green Books.

Benson, Peter, and Stuart Kirsch. 2010. Corporate oxymorons. Dialectical Anthropology 34(1): 45-48.

Blumenstyk, Goldie. 2007. Mining company involved in environmental disaster now advises sustainability institute at U. of Michigan. Chronicle of Higher Education 54(15): A22.

Bruno, Kenny. 2000. BP: beyond petroleum or beyond preposterous? Corpwatch. 14 Dec 2000. Electronic document, accessed 30 May 2010. http://www.corpwatch.org/article.php?id=219.

Brundtland, G.H. (ed.). 1987. Our common future: the world commission on environment and development. Oxford: Oxford University Press.

Chapin, Mac. 2004. A challenge to conservationists. Worldwatch Magazine 17(6): 17-31.

Economist, The. 1999. Mea copper, mea culpa. Australia's Broken Hill Proprietary may pull out of New Guinea. The Economist. 21 Aug, 58.

Finch, Bill. 2010. Gulf spill update: the numbers don't lie. Cool green science: The conservation blog of the Nature Conservancy. 26 May. Electronic document, accessed 15 June. http://www.blog.nature. org/2010/05/gulf-spill-update-the-numbers-dont-lie/.

Hoffman, Andrew J. 1997. From heresy to dogma: an institutional history of corporate environmentalism. San Francisco: The New Lexington Press.

Kirsch, Stuart. 2006. Reverse anthropology: indigenous analysis of social and environmental relations in New Guinea. Stanford: Stanford University Press.

Kottak, Conrad Phillip. 2009. Anthropology: the exploration of human diversity, 13th ed. Boston: McGraw Hill.

Speth, James Gustave. 2008. The bridge at the edge of the world: capitalism, the environment, and crossing from crisis to sustainability. New Haven: Yale University Press.

Stephens, Joe. 2010. Nature Conservancy faces potential backlash from ties with BP. The Washington Post. 24 May 2010. Electronic document, accessed 24 May. http://www.washingtonpost.com/ wp-dyn/content/article/2010/05/23/AR2010052302164_pf.html.

Strathern, Marilyn. 2000. Introduction: new accountabilities. In Audit cultures: anthropological studies in accountability, ethics, the academy, ed. Marilyn Strathern, 1-19. New York: Routledge.

Thompson, Clive. 2008. A green coal baron? The New York Times Magazine. 22 June, 2008. Electronic document, accessed 22 June 2008. http://www.nytimes.com/2008/06/22/magazine/22Rogers-t. html?_r=1\&ref=duke_energy_corporation.

Uhlmann, David M. 2010. Prosecuting crimes against the Earth. The New York Times. A23. Friday 4 June 2010.

Watts, Michael, and Ed Kashi. 2008. Curse of the black gold: 50 years of oil in the Niger Delta. Brooklyn: Powerhouse Books. 